\title{
PENGARUH UKURAN PERUSAHAAN, KOMPLEKSITAS OPERASI PERUSAHAAN DAN REPUTASI KAP TERHADAP AUDIT DELAY ( Studi Kasus Pada Perusahaan Manufaktur Sektor Industri Barang Konsumsi Sub Sektor Makanan dan Minuman di Bursa Efek Indonesia tahun 2014-2018 )
}

\author{
Natrion, ST., SE., M.Ak \\ Mirawati Dewi \\ natribach@gmail.com, dewimirawati5@,gmail.com
}

\section{Fakultas Ekonomi - Program Studi Akuntansi Universitas Satya Negara Indonesia}

\begin{abstract}
ABSTRAK
Laporan Keuangan adalah sesuatu yang sangat dibutuhkan suatu perusahaan dalam pengambilan keputusan dan menarik seorang investor untuk berinvestasi ke dalam perusahaan, Penyampaian laporan keuangan adalah segala aspek yang berkaitan dengan penyampaian informasi- informasi dan pengukuran secara ekonomi mengenai sumber daya serta berbagai pihak yang mempunyai kepentingan dalam informasi tersebut.

Dalam penelitian ini bertujuan untuk mengetahui pengaruh dari ukuran perusahaan, kompleksitas operasi perusahaan, dan reputasi kap terhadap audit delay, baik secara parsial maupun simultan. Populasi dari penelitian ini adalah perusahaan manufaktur sektor industri barang konsumsi sub sektor makanan dan minuman di Bursa Efek Indonesia (BEI) periode 2014-2018. Pengambilan sampel penelitian dilakukan dengan teknik purposive sampling dan didapatkan 10 perusahaan dengan 5 tahun pengamatan. Dengan demikian total sampel yang diteliti adalah 50 perusahaan. Data yang digunakan adalah data sekunder, yaitu data yang di ambil di Bursa Efek Indonesia (BEI) dan Metode yang digunakan untuk menganalisis hubungan antar variabel adalah metode regresi logistik.

Hasil penelitian ini menunjukkan secara parsial ukuran perusahaan berpengaruh terhadap audit delay sedangkan kompleksitas operasi perusahaan dan reputasi kap tidak berpengaruh terhadap audit delay, namun secara bersama - sama (simultan) semua variabel berpengaruh terhadap audit delay. Dengan penelitian ini diharapkan dapat memberikan Implikasi dan Informasi bagi pihak - pihak yang terkait dalam memprediksi waktu dan ketepatan penyampaian laporan keuangan.
\end{abstract}

Kata Kunci : Ukuran perusahaan, Kompleksitas Operasi perusahaan, Reputasi KAP, Audit delay. 


\section{PENDAHULUAN}

Laporan Keuangan adalah sesuatu yang sangat dibutuhkan suatu perusahaan dalam pengambilan keputusan dan menarik seorang investor untuk berinvestasi ke perusahaan tersebut, laporan keuangan merupakan catatan informasi keuangan suatu perusahaan pada suatu periode tertentu, laporan keuangan adalah bagian dari proses penyampaian laporan keuangan, laporan keuangan yang lengkap biasanya meliputi : laporan laba rugi yang komprehensif, laporan keuangan harus memberikan informasi yang tepat waktu, akurat dan dapat dipertanggung jawabkan. Laporan keuangan merupakan salah satu informasi yang dibutuhkan oleh para investor untuk berinvestasi di suatu perusahaan, dan bagi pihak manajemen laporan keuangan digunakan untuk bahan pertimbangan perusahaan untuk periode mendatang. Penyampaian laporan keuangan adalah segala aspek yang berkaitan dengan penyampaian informasiinformasi dan pengukuran secara ekonomi mengenai sumber daya serta berbagai pihak yang mempunyai kepentingan dalam informasi tersebut, perusahaan akan selalu menyampaikan laporan keuangan yang baik dan benar maka dengan adanya hal tersebut dibutuhkan seseorang yang melakukan pemeriksaan laporan keuangan tersebut yaitu seorang Auditor Independen. Dalam penelitian (Wardhana 2014) menyatakan bahwa ketepatan waktu penyampaian laporan keuangan merupakan elemen pokok atas laporan keuangan dan oleh karena itu laporan keuangan sebaiknya disampaikan tepat waktu.

Menurut (Kartika, 2011) Audit delay merupakan lamanya atau rentang waktu penyelesaian audit yang diukur dari tanggal diterbitkannya laporan audit. Keterlambatan penyampaian laporan keuangan suatu perusahaan akan menimbulkan reaksi negatif bagi para investor. Karena ketepatan waktu penyampaian laporan keuangan untuk dijadikan bahan pertimbangan pada saat melakukan investasi dan pengambilan keputusan.

Salah satu faktor yang mempengaruhi audit delay adalah ukuran perusahaan. Ukuran perusahaan merupakan besarnya atau luas perusahaan dalam menjalankan operasinya. Menurut Innayati \& Susilowati(2015) Ukuran perusahaan dapat ditentukan melalui total aset yang dimiliki perusahaan, semakin besar total aset perusahaan maka semakin besar pula ukuran suatu perusahaan. Ukuran perusahaan dapat dikategorikan menjadi tiga yaitu, perusahaan besar, perusahaan menengah dan perusahaan kecil (Widyastuti, 2016) dan Ukuran perusahaan berpengaruh positif terhadap audit delay, hal ini terjadi karena perusahaan yang lebih besar memiliki sistem pengendalian internal yang lebih baik dibandingkan dengan perusahaan kecil, sedangkan menurut Kartika (2011) menunjukkan bahwa ukuran perusahaan berpengaruh negatif pada audit delay. Menurut penelitian dari (Widosari, 2012) semakin besar ukuran perusahaan semakin lama audit delay yang dialami perusahaan, sedangkan menurut (Rachmawati, 2008) dan (Yulianti, 2011) dalam penelitiannya menemukan bahwa ukuran perusahaan berpengaruh pada audit delay. Hasil yang berbeda ditemukan (Sunaningsih, 2014) dalam penelitiannya menunjukkan ukuran perusahaan tidak berpengaruh pada audit delay.

Jurnal Ilmiah Akuntansi dan Ekonomi Volume. 1 Nomor. 5 Februari 2020

Hal. 49 
Perusahaan yang memiliki anak cabang perusahaan cenderung mengalami berbagai kesulitan dan masalah dalam operasional perusahaan. Ketergantungan yang semakin kompleks terjadi apabila organisasi dengan berbagai jenis atau jumlah pekerjaan menimbulkan masalah dan organisasi yang lebih rumit. Menurut Penelitian dari (Ningsih, 2014) yang menyatakan kompleksitas operasi perusahaan tidak berpengaruh terhadap audit delay, sedangkan menurut Saputri (2012) perpanjangan audit delay dapat disebabkan oleh kompleksitas operasi perusahaan, hal tersebut disebabkan karena pada auditor membutuhkan waktu yang lebih lama untuk melakukan proses audit diperusahaan yang memiliki kompleksitas operasi.

Reputasi KAP menunjukan bahwa reputasi KAP yang diukur dari adanya afiliasi dengan the big four atau tidak memang secara signifikan berpengaruh negatif terhadap lamanya waktu penyelesaian laporan audit, karena KAP yang masuk the big four dengan yang non the big four memiliki karakteristik yang berbeda, KAP yang masuk the big four akan lebih profesional dibandingkan dengan KAP yang tidak masuk ke dalam the big four, dalam penelitian Pratama(2014) keempat KAP yang berafiliasi dengan KAP di Indonesia yaitu : (1)KAP Price Waterhouse Coopers, yang bekerja sama dengan KAP Tanudiredja, Wibisana \& rekan. (2) KAP KPMG (Klynveld Peat Marwick Goerdeler) yang bekerja sama dengan KAP Siddharta dan Widjaja, (3) KAP Ernst \& Young, yang bekerja sama dengan KAP Purwantono, (4) KAP Deloitte Touche Tohmatsu, yang bekerja sama dengan KAP Osman Bing Satrio. Hasil dari penelitian Indah Permata sari (2014) membuktikan bahwa reputasi KAP berpengaruh terhadap audit delay sedangkan hasil penelitian (Verawati dan Wirakusuma, 2016) menunjukan bahwa reputasi KAP tidak berpengaruh terhadap audit delay.

Berdasarkan latar belakang masalah yang telah dipaparkan, beberapa penelitian dilakukan dengan cara memperoleh data sekunder yaitu data yang telah diolah terlebih dahulu dan data yang hanya memperhatikan output, sedangkan dalam hal ketepatan waktu penyampaian laporan keuangan auditor adalah pihak yang berperan penting dari proses awal audit hingga terbitnya laporan keuangan. Oleh karena itu, peneliti mengambil judul penelitian "Pengaruh Ukuran perusahaan, Kompleksitas Operasi Perusahaan dan Reputasi KAP terhadap Audit Delay".

\section{LANDASAN TEORI}

\section{Pengertian Auditing}

Menurut Agus Sukrisno (2012 : 4) Auditing adalah suatupemeriksaan yang dilakukan secara kritis dan sistematis, oleh pihak yang independen, terhadap laporan keuangan yang telah disusun oleh manajemen, beserta catatan - catatan pembukuan dan bukti - bukti pendukungnya, dengan tujuan untuk dapat memberikan pendapat mengenai kewajaran laporan keuangan tersebut.

Auditing adalah suatu proses sistematik untuk memperoleh dan mengevaluasi bukti secara ojektif mengenai pernyataan-pernyataan tentang kegiatan dan kejadian ekonomi, dengan tujuan untuk menetapkan tingkat kesesuaian antara pernyataan- 
pernyataantersebut dengan kriteria yang telah ditetapkan, serta penyampaian hasilhasilnya kepada pemakai yang berkepentingan Mulyadi (2002 : 9).

Dari pengertian diatas dapat disimpulkan pengertian auditing adalah suatu pemeriksaan, pengumpulan, dan pengevaluasian data dan informasi tentang laporan keuangan perusahaan yang dilakukan secara sistematis dan kritis mengenai suatu kewajaran laporan keuangan keuangan tersebut.

\section{Laporan keuangan}

Menurut Ikatan Akuntan Indonesia(2009) laporan keuangan merupakan bagian dari proses pelaporan keuangan. Laporan keuangan yang lengkap biasanya meliputi neraca, laporan labarugi, laporan perubahan posisi keuangan (yang dapat disajikan dalam berbagaicara seperti, misalnya sebagai laporan arus kas atau laporan arus dana), catatan dan laporan lain serta materi penjelasan yang merupakan bagian integral dari laporan keuangan.

Laporan keuangan merupakan media komunikasi yang digunakan oleh manajemen kepada pihak luar perusahaan. Kualitas komunikasi yang dicapai akan tergantung dengan kualitas laporan keuangan. Untuk mendukung tercapainya kualitas laporan keuangan yang baik, maka diperlukan adanya aturan (regulasi) yang dibuat oleh profesi (dewan pembuat standar) dan Pemerintah (Saputri, 2012).

Dalam Standar Akuntansi Keuangan (PSAK) Laporan Keuangan adalah :

"Laporan keuangan yang menyediakan informasi menyangkutposisi keuangan, kinerja, serta perubahan posisi keuangan perusahaanyang ditujukan untuk memenuhi kebutuhan bersama sebagaian besarpengguna laporan”.(IAI, 2012).

Berdasarkan beberapa pengertian di atas dapat disimpulkanLaporan Keuangan adalah:

1) Merupakan produk akuntansi yang penting dan dapat digunakanuntuk membuat keputusan-keputusan ekonomi bagi pihak internaldan eksternal.

2) Merupakan potret perusahaan, yaitu dapat menggambarkan kinerja keuangan maupun kinerja manajemen perusahaan dalam setiap kondisi.

3) Merupakan rangkaian aktivitas ekonomi perusahaan yang diklasifikasikan dalam suatu periode perusahaan dalam kurun waktu setahun.

4) Merupakan ringkasan dari suatu proses transaksi-transaksi keuangan yang terjadi selama periode yang bersangkutan.

\section{Laporan Audit (Audit Report)}

Menurut (Mulyadi, 2017: 410) Laporan audit disusun setelah auditor menyelesaikan pekerjaan lapangan (audit file works) ada dua bentuk laporan audit yaitu laporan audit bentuk pendek dan laporan audit bentuk panjang. Pertimbangan yang digunakan oleh auditor dalam menerbitkan laporan audit bentuk pendek atau panjang tergantung pada kebutuhan klien. Kebutuhan klien ini biasanya ditentukan oleh kebutuhan pemakai laporan audit(misalnya bank dan pemegang saham). Ditinjau dari isinya, laporan audit bentuk panjang merupakan perluasan isi laporan audit bentuk pendek. 
Laporan audit bentuk pendek baku terdiri dari tiga paragraf yaitu paragraf pengantar, paragraf lingkup dan paragraf pendapat. Dalam penyajiannya, laporan audit bentuk pendek ini melampirkan dengan laporan keuangan auditan dan catatan atas laporan keuangan auditan tersebut. Sebagaimana dijelaskan dalam paragraf pengantar laporan audit, laporan keuangan auditan adalah tanggung jawab manajemen perusahaan. Dan karena catatan atas laporan keuangan merupakan bagian tidak terpisahkan dari laporan keuangan, maka catatan atas laporan keuangan merupakan tanggung jawab manajemen pula. Dengan demikian hanya laporan audit yang menjadi tanggung jawab auditor.

\section{Audit Delay}

Menurut (Kartika, 2011 : 155 ) Audit delay merupakan lamanya atau rentang waktu penyelesaian audit yang diukur dari tanggal penutupan tahun buku sampai dengan tanggal diterbitkannya laporan audit. Audit Delay inilah yang dapat mempengaruhi ketepatan informasi yang dipublikasikan, sehingga akan berpengaruh terhadap tingkat ketidakpastian keputusan yang berdasarkan informasi yang dipublikasikan.

Menurut (Widyastuti, 2017 : 1086) Audit delay merupakan perbedaan waktu antara tanggal laporan keuangan dengan tanggal opini audit dalam laporan keuangan menunjukan tentang lamanya waktu penyelesaian audit, jadi dapat disimpulkan bahwa audit delay merupakan keterlambatan pelaporan keuangan perusahaan yang dapat menyebabkan opini negatif dari seorang investor yang akan melakukan kegiatan investasi ke perusahaan tersebut, dan menurut (Widosari \& Sinta, 2012 ) Audit Delay yang melewati batas waktu ketentuan Bapepam-LK, tentu berakibat pada keterlambatan publikasi laporan keuangan. Keterlambatan publikasi laporan keuangan tersebut dapat mengindikasikan adanya masalah dalam laporan keuangan emiten, sehingga memerlukan waktu yang lebih lama dalam penyelesaian audit.

Dalam penelitian Chotimah (2018) Ketepatan waktu penyusunan atau pelaporan suatu laporan keuangan perusahaan bisa berpengaruh pada nilai laporan keuangan tersebut. Keterlambatan informasi akan menimbulkan reaksi negatif dari pelaku pasar modal. Informasi laba yang dihasilkan perusahaan dijadikan sebagai salah satu dasar pengambilan keputusan untuk membeli atau menjual kepemilikan yang dimiliki oleh investor. Artinya, informasi yang dipublikasikan tersebut akan menyebabkan kenaikan atau penurunan harga saham.

\section{Hubungan Ukuran Perusahaan dengan Audit Delay}

Total kekayaan atau total aset yang dimiliki oleh suatu perusahaan ternyata berpengaruh terhadap Audit delay. Perusahaan yang memiliki total asset yang lebih besar akan menyelesaikan audit lebih lama dibandingkan dengan perusahaan yang mempunyai total asset lebih kecil, dikarenakan jumlah sampel yang harus diambil semakin besar dan semakin banyak prosedur audit yang harus ditempuh oleh auditor. Menurut penelitian Widyastuti (2016 : 12 ) membuktikan bahwa ukuran perusahaan 
berpengaruh terhadap Audit delay, dimana ukuran perusahaan yang diproksikan dalam total asset mempengaruhi peningkatan waktu audit.

H1 : Ukuran Perusahaan berpengaruh signifikan terhadap Audit Delay.

\section{Hubungan Kompleksitas Operasi Perusahaan dengan Audit Delay}

Perusahaan yang memiliki anak perusahaan dan yang tidak memiliki anak perusahaan membuktikan bahwa perusahaan memiliki unit lebih banyak yang harus di periksa terlebih dahulu, sehingga seorang audit memerlukan waktu yang lebih lama dalam proses audit . Menurut penelitian Angruningrum dan Wirakusuma (2013 : 265) menyimpulkan bahwa kompleksitas operasi Audit tidak berpengaruh terhadap Audit delay.

H2 : Kompleksitas Operasi Perusahaan tidak berpengaruh signifikan terhadap Audit Delay

\section{Hubungan Reputasi KAP dengan Audit Delay}

Berdasarkan hasil pengamatan lamanya audit delay yang dilakukan oleh KAP the big four dan non big four memperlihatkan beberapa perbedaan. Perusahaan yang diaudit oleh KAP the big fourakan lebih cepat mempublikasikan laporan keuangannya daripada perusahaan yang diaudit oleh KAP non big four. KAP yang berafiliasi dengan the big four memperoleh insentif yang lebih besar dan memiliki sumber daya yang lebih besar, baik secara kuantitatif maupun kualitataif, sehingga KAP ini dapat menjalankan pengauditan secara lebih efisien dan efektif, serta memiliki fleksibilitas yang lebih tinggi dalam penjadwalan audit. Juga adanya reputasi yang harus mereka jaga jika pengauditan yang dilakukan berjalan lambat tentunya akan mengurangi kompetensi mereka dimata klien.

Menurut penelitian Widyastuti (2016 : 13 ) Hasil dari penelitiannya menyimpulkan bahwa suatu KAP yang berafiliasi the big four mempengaruhi waktu pelaporan audit berbanding terbalik dengan KAP yang tidak berafiliasi atau non the big four .

H3 : Reputasi KAP tidak berpengaruh signifikan terhadap Audit Delay 


\section{METODE PENELITIAN}

Metode Penelitian ini menggunakan metode penelitian Kausal. Data yang digunakan dalam penelitian ini adalah data sekunder berupa laporan keuangan tahunan (Annual Report), Teknik pengumpulan data menggunakan teknik dokumentasi. Analisis Uji Regresi Logistik regression digunakan untuk menguji apakah probabilitas terjadinya variabel dependen dapat diprediksi oleh variabel independen ( Statistik Deskriptif, Hasil Uji Kelayakan Model Regresi, Hasil Uji Kesesuaian Keselurahan Model (Overall Model Fit), Hasil Uji Koefisien Determinasi (Nagelkerke R. Square), Hasil Uji Regresi Logistik dan Uji Klasifikasi).

$$
\operatorname{Ln} \mathbf{Y}=\alpha+\boldsymbol{\beta} 1 \mathbf{X}_{1}+\beta 2 \mathbf{X}_{2}+\beta 3 \mathbf{X}_{3}+\mathbf{C}
$$

Keterangan:

LnY $=$ Variabel Dummy Audit Delay

$\alpha \quad=$ Konstanta

$\beta 1=$ Ukuran Perusahan

$\beta 2=$ Kompleksitas Operasi Perusahaan

$\beta 3=$ Reputasi KAP

$\mathrm{C}=$ Error Term / Residual / Variabel Pengganggu

Berdasarkan adalah kerangka penelitian dapat digambarkan sebagai berikut .

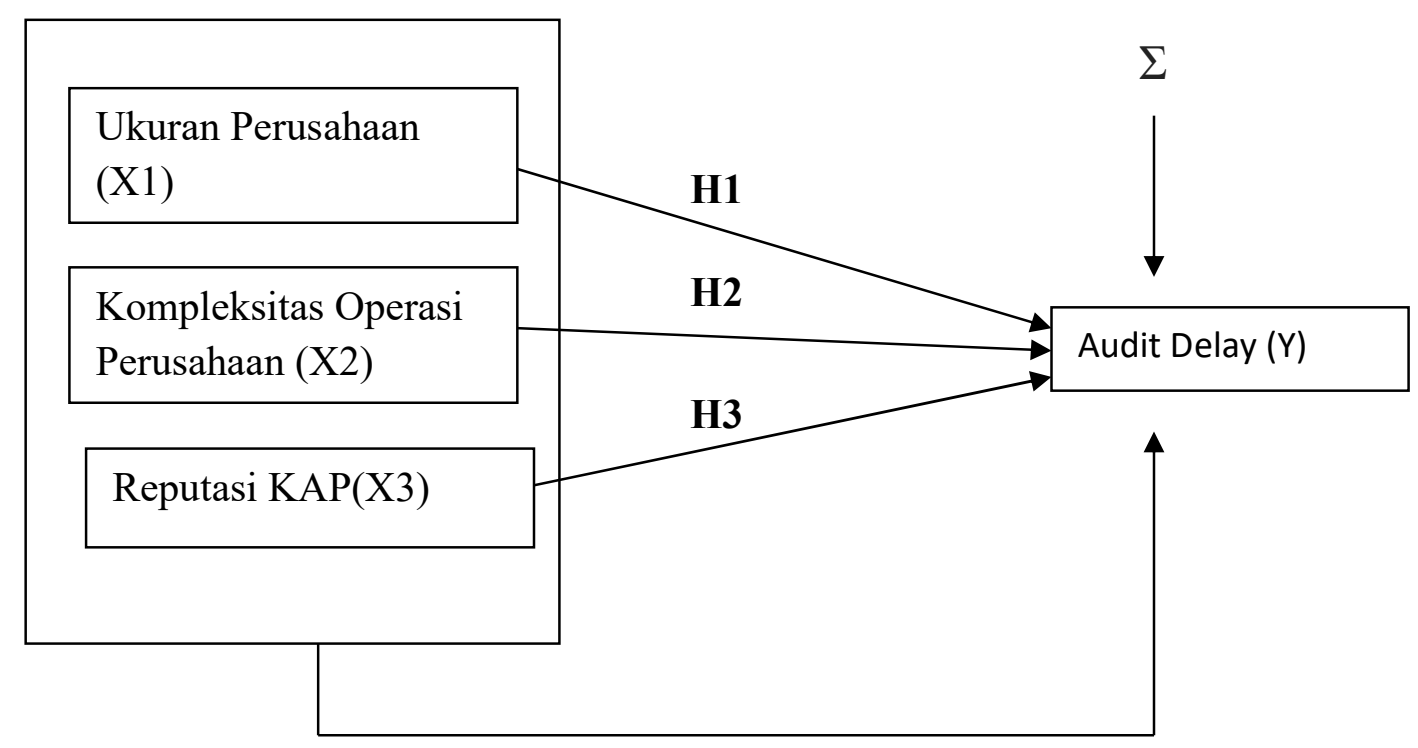

GAMBAR 2.2

Kerangka Pemikiran 
Berdasarkan gambar 2.2 menunjukan pengaruh ukuran perusahaan (X1), Kompleksitas Operasi Perusahaan (X2) dan Reputasi KAP (X3) terhadap Audit

Delay.Baik secara parsial maupun simultan dalam penelitian ini.

\section{Operasional Variabel}

Tabel 3.1 Operasional Variabel

\begin{tabular}{|c|c|c|c|}
\hline NO & Variabel & Indikator & Skala \\
\hline 1 & $\begin{array}{l}\text { Ukuran Perusahaan }\left(\mathrm{X}_{1}\right) \\
\text { Sumber : Widyastuti }(2016)\end{array}$ & $\begin{array}{l}\text { Ukuran perusahaan }= \\
\text { Ln(total aset) }\end{array}$ & Ratio \\
\hline 2 & $\begin{array}{l}\text { Kompleksitas } \text { Operasi } \\
\text { Perusahaan }\left(\mathrm{X}_{2}\right) \\
\text { Sumber: Angruningrum dan } \\
\text { Wirakusuma }(2013)\end{array}$ & $\begin{array}{l}\text { Kode } 1=\text { anak perusahaan } \\
\text { Kode } 0=\text { tidak memiliki } \\
\text { anak perusahaan }\end{array}$ & Nominal \\
\hline 3 & $\begin{array}{l}\text { Reputasi KAP }\left(\mathrm{X}_{3}\right) \\
\text { Sumber : (Innayati dan } \\
\text { Susilowati, 2015) }\end{array}$ & $\begin{array}{l}\text { Kode } 1=\text { the big four } \\
\text { Kode } 0=\text { non the big four }\end{array}$ & Nominal \\
\hline 4 & $\begin{array}{l}\text { Audit Delay (Y) } \\
\text { Sumber : (Kartika, 2011) }\end{array}$ & $\begin{array}{l}\text { Kode } 1=>90 \text { Hari Delay } \\
\text { Kode } 0=<90 \text { Hari tepat } \\
\text { waktu. }\end{array}$ & Nominal \\
\hline
\end{tabular}

PEMBAHASAN

Hasil Uji Statistik Deskriptif

Tabel 4.3

Descriptive Statistics

\begin{tabular}{|l|c|c|c|c|c|}
\hline & $\mathrm{N}$ & Minimum & Maximum & Mean & $\begin{array}{c}\text { Std. } \\
\text { Deviation }\end{array}$ \\
\hline Ukuran Perusahaan & 50 & 27.62 & 32.20 & 29.1616 & 1.42381 \\
Kompleksitas Operasi & 50 & 0 & 1 & .60 & .495 \\
Perusahaan & 50 & 0 & 1 & .60 & .495 \\
Reputasi KAP & 50 & 0 & 1 & .24 & .431 \\
Audit Delay & 50 & & & & \\
Valid N (listwise) & & & &
\end{tabular}

Sumber : Output spss

Jurnal Ilmiah Akuntansi dan Ekonomi Volume. 1 Nomor. 5 Februari 2020

Hal. 55 
Berdasarkan Tabel 4.3, hasil analisis dengan menggunakan statistik deskriptif dijelaskan sebagai berikut :

Hasil analisis statistik deskriptif terhadap Audit Delay menunjukkan nilai minimum sebesar 0 , nilai maksimum sebesar 1 dengan rata -rata sebesar 0,24 dan standar deviasi sebesar 0,431 . Nilai rata - rata sebesar 0,24 menunjukkan bahwa audit Delay dengan kode 1 menunjukkan bahwa sampel penelitian lebih sedikit menerima audit delay dari 50 sampel yang diteliti.

\section{Hasil Uji Hipotesis Penelitian}

Tahapan dalam pengujian dengan menggunakan uji regresi logistik data dapat dijelaskan sebagai berikut (Ghozali, 2016).

\section{Hasil Uji Kelayakan Model Regresi}

Dari Tabel di bawah dapat menunjukan hasil pengujian Hosmer and Lemeshow's Test. Berdasarkan Tabel tersebut, dapat di lihat bahwa nilai signifikansi sebesar 0,114 . Nilai signifikan yag diperoleh tersebut diatas 0,05 yang berarti Ho diterima. Hal ini berarti model mampu memprediksi nilai observasinya atau model dapat diterima karena cocok dengan data observasi. sehingga model dapat digunakan untuk analisis selanjutnya.

Hosmer and Lemeshow Test

\begin{tabular}{|l|l|l|l|}
\hline Step & Chi-square & df & Sig. \\
\hline 1 & 12.925 & 8 & .114 \\
\hline
\end{tabular}

Sumber : Data olah SPSS

\section{Hasil Uji Kesesuaian Keselurahan Model (Overall Model Fit)}

\begin{tabular}{|c|c|c|c|}
\hline \multicolumn{4}{|c|}{ Iteration History ${ }^{\mathrm{a}, \mathrm{b}, \mathrm{c}}$} \\
\hline \multirow[b]{2}{*}{ Iteration } & & \multirow[b]{2}{*}{-2 Log likelihood } & Coefficients \\
\hline & & & Constant \\
\hline Step 0 & 1 & 55.226 & -1.040 \\
\hline & 2 & 55.108 & -1.150 \\
\hline & 3 & 55.108 & -1.153 \\
\hline & 4 & 55.108 & -1.153 \\
\hline
\end{tabular}

a. Constant is included in the model.

b. Initial -2 Log Likelihood: 55.108

c. Estimation terminated at iteration number 4 because parameter estimates changed by less than .001 . 
Menurut (Ghozali, 2016 :328) Berdasarkan hasil pegolahan SPSS 22.0, pada Tabel diatas menunjukan bahwa nilai -2 Log Likelihood awal (Tabel Iteration History 0) adalah sebesar 55,108 Secara matematis, angka tersebut signifikan pada alpha 5\% dan berarti bahwa Ho ditolak. Hal ini berarti hanya konstanta saja yang tidak fit dengan data (sebelum dimasukkan variabel bebas ke dalam model regresi) Langkah selanjutnya yaitu dengan membandingkan antara nilai -2 Log Likelihood awal ( Tabel Iteration History 0) dengan -2 Log Likelihood akhir (Tabel Iteration History 1), Pada Tabel Iteration History 0, nilai -2 Log Likelihood awal menunjukan sebesar 55,108.

\section{Hasil Uji Koefisien Determinasi (Nagelkerke R. Square)}

\begin{tabular}{|l|c|c|c|}
\hline & $\begin{array}{c}\text { Model Summary } \\
-2 \text { Log } \\
\text { Step }\end{array}$ & $\begin{array}{c}\text { Cox \& Snell R } \\
\text { Square }\end{array}$ & $\begin{array}{c}\text { Nagelkerke R } \\
\text { Square }\end{array}$ \\
\hline 1 & $24.997^{\mathrm{a}}$ & .452 & .677 \\
\hline
\end{tabular}

a. Estimation terminated at iteration number 20 because maximum iterations has been reached. Final solution cannot be found.

Sumber : data olah SPSS

Dari data Tabel diatas maka diperoleh hasil uji model -2Log Likelihood menghasilkan 24,997 dari koefisien determinasi yang dilihat dari Nagelkerke R Square adalah 0,677 (67,7 \%) dan nilai Cox \& Snell R Square 0,452 (45,2\%). berarti variabel dependen dapat dijelaskan oleh variabel independen sebesar $67,7 \%$, sedangkan sisanya sebesar 32,3\% dijelaskan faktor-faktor lain di luar penelitian ini, contohnya seperti : Profitabilitas, Leverage, Solvabilitas, Opini Audit, Kondisi Keuangan dan Komite Audit.

\section{Hasil Uji Regresi Logistik}

\section{a. Regresi Logistik}

Variables in the Equation

\begin{tabular}{|cc|c|c|c|c|c|c|}
\hline & & & & & & & \\
& & B & S.E. & Wald & df & Sig. & Keterangan \\
\hline Step & X1 & -1.770 & .738 & 5.744 & 1 & .017 & Berpengaruh \\
$1^{\mathrm{a}}$ & X2 & 24.662 & 8672.021 & .000 & 1 & .998 & Tidak Berpengaruh \\
& X3 & 1.978 & 2.111 & .878 & 1 & .349 & Tidak Berpengaruh \\
& Constant & 26.642 & 8672.041 & .000 & 1 & .998 & - \\
\hline
\end{tabular}

Variable(s) entered on step 1: X1, X2, X3. 
Variabel konstanta pada model regresi logistik ini mempunyai nilai Positif yaitu sebesar 26,642 yang berarti tanpa adanya variabel lain maka audit delay bernilai sebesar 26,642 satuan.

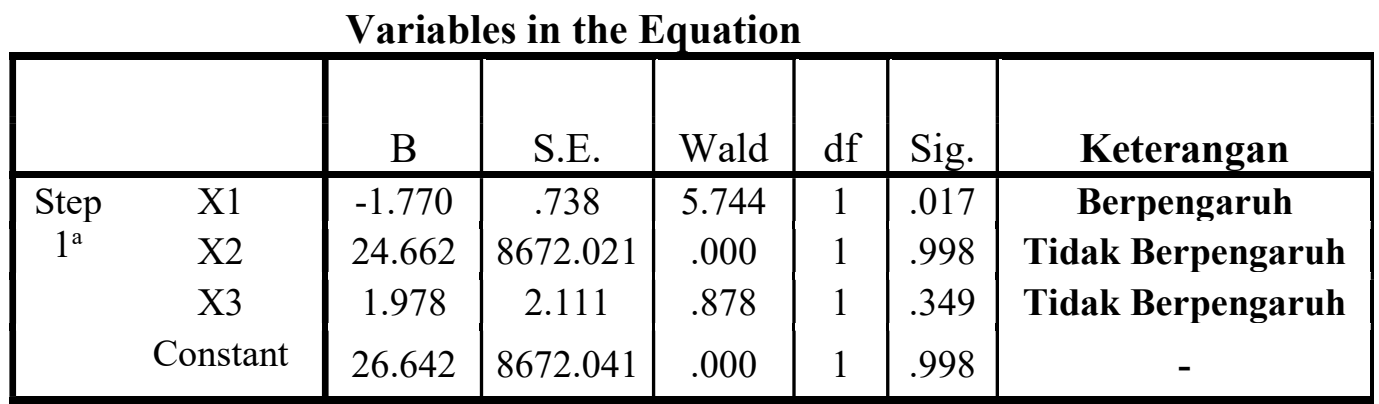

a. Variable(s) entered on step 1: X1, X2, X3.

\section{b. Pengujian Secara Parsial}

Model regresi logistik dapat di lihat pada Tabel dibawah ini:

Berdasarkan Tabel di atas maka model regresi logistik yang diperoleh adalah sebagai berikut:

$$
\begin{aligned}
& \operatorname{Ln} \mathrm{Y}=26,642-1,770 \mathrm{X} 1+24,662 . \mathrm{X} 2+1,978 . \mathrm{X} 3+€ \\
& \text { Keterangan : } \\
& \operatorname{Ln} \mathrm{Y} \quad=\text { Variabel Dummy Audit Delay } \\
& \alpha \quad=\text { konstanta } \\
& \beta \quad=\text { koefisien variabel } \\
& \mathrm{X} 1=\text { Ukuran Perusahaan } \\
& \mathrm{X} 2=\text { Kompleksitas Operasi Perusahaan } \\
& \text { X3 = Reputasi KAP } \\
& €=\quad=\text { Error Term / Residual / Variabel Pengganggu }
\end{aligned}
$$

Variabel ukuran perusahaan memiliki statistik wald sebesar 5,774 sedangkan berdasarkan Tabel Chi-Square dengan tingkat signifikansi 0,05 dan tingkat kebebasan sebesar 1 diperoleh hasil 12,925 . Nilai signifikansi Ukuran Perusahaan menghasilkan nilai yang lebih kecil dari 0,05 yaitu memiliki nilai sebesar 0,017. Dengan demikian Ha1 diterima dan Hol ditolak yang menyatakan bahwa ukuran perusahaan berpengaruh signifikan terhadap audit delay.

Variabel kompleksitas operasi perusahaan memiliki statistik wald sebesar 0 sedangkan berdasarkan Tabel Chi-Square dengan tingkat signifikansi 0,05 dan tingkat kebebasan sebesar 1 diperoleh hasil 12,925. Nilai signifikansi komplekitas operasi 
perusahaan menghasilkan nilai yang lebih besar dari 0,05 yaitu memiliki nilai sebesar 0,998 . Dengan demikian Ha2 ditolak dan Ho2 diterima yang menyatakan bahwa kompleksitas operasi perusahaan tidak berpengaruh signifikan terhadap audit delay.

Variabel Reputasi KAP memiliki statistik wald sebesar 0,878 sedangkan berdasarkan Tabel Chi-Square dengan tingkat signifikansi 0,05 dan tingkat kebebasan sebesar 1 diperoleh hasil 12,925. Nilai signifikansi Reputasi KAP menghasilkan nilai yang lebih besar dari 0,05 yaitu memiliki nilai sebesar 0,349. Dengan demikian Ha3 ditolak dan Ho3 diterima yang menyatakan bahwa Reputasi KAP tidak berpengaruh signifikan terhadap audit delay.

\section{c. Pengujian Secara Simultan}

\section{Omnibus Tests of Model Coefficients}

\begin{tabular}{|ll|l|l|l|}
\hline & & Chi-square & df & Sig. \\
\hline Step 1 & Step & 30.111 & 3 & .000 \\
& Block & 30.111 & 3 & .000 \\
& Model & 30.111 & 3 & .000 \\
\hline
\end{tabular}

Berdasarkan Tabel di atas menunjukkan bahwa secara simultan Ukuran perusahaan, Kompleksitas Operasi Perusahaan dan Reputasi KAP dapat menjelaskan mengenai Audit Delay. Hal ini dilihat dari hasil Chi Square sebesar 30,111 dengan df sebesar 3 dan signifikansi sebesar 0,000 yang nilainya lebih kecil dari 0,05 atau nilai Chi Square hitung 30,111 lebih besar dari Chi Square tabel 7,81473. Hal ini menunjukkan bahwa Ha4 diterima, sehingga dapat disimpulkan ukuran perusahaan, kompleksitas operasi perusahaan berpengaruh secara simultan terhadap audit delay.

\section{Uji Klasifikasi}

Tabel Uji Klasifikasi 2 x 2 menghitung nilai estimasi yang benar (correct) dan salah (incorrect). Nilai klasifikasi dapat dilihat pada tabel dibawah ini:

\begin{tabular}{|c|c|c|c|c|}
\hline \multicolumn{5}{|c|}{ Classification Table ${ }^{\mathrm{a}}$} \\
\hline & \multirow[b]{3}{*}{ Observed } & \multicolumn{3}{|c|}{ Predicted } \\
\hline & & \multicolumn{2}{|c|}{ Audit Delay } & \multirow{2}{*}{$\begin{array}{l}\text { Percentage } \\
\text { Correct }\end{array}$} \\
\hline & & Tidak Delay & Delay & \\
\hline \multirow[t]{3}{*}{ Step 1} & Audit Delay & 36 & 2 & 94.7 \\
\hline & $\begin{aligned} \text { Delay } \\
\end{aligned}$ & 2 & 10 & 83.3 \\
\hline & Overall Percentage & & & 92.0 \\
\hline
\end{tabular}

a. The cut value is .500

Sumber : Data Output SPSS 
Hasil data klasifikasi menunjukkan kekuatan prediksi dari model regresi untuk memprediksi kemungkinan perusahaan melakukan audit delay. Kekuatan prediksi dari model regresi adalah untuk memprediksi kemungkinan perusahaan melakukan audit delay adalah sebesar 83,3\%. Hal ini dapat menunjukkan bahwa menggunakan model regresi yang digunakan terdapat sebanyak 10 sampel $(83,3 \%)$ yang diprediksi akan melakukan audit delay dari total 50 sampel yang melakukan audit delay. Kekuatan prediksi dari model regresi untuk memprediksi kemungkinan perusahaan tidak melakukan audit delay adalah sebesar $94,7 \%$, berarti bahwa dengan menggunakan model regresi yang digunakan terdapat sebanyak 36 sampel (94,7\%) yang diprediksi tidak akan melakukan audit delay dari total 50 sampel.

\section{HASIL PEMBAHASAN PENELITIAN}

\section{Pengaruh Ukuran Perusahaan (X1) terhadap Audit Delay}

Dalam penelitian ini menunjukan bahwa Variabel ukuran perusahaan menghasilkan koefisien regresi negatif sebesar 1,770, dengan tingkat signifikansi (p) sebesar 0,017 lebih kecil dari $\alpha=5 \%$. Dengan tingkat signifikansi yang lebih kecil dari $\alpha=5 \%$ maka Ha 1 diterima dan Ho1 ditolak.

\section{Pengaruh Kompleksitas Operasi Perusahaan (X2) terhadap Audit Delay}

Dalam penelitian ini menunjukan Variabel Kompleksitas Operasi Perusahaan menghasilkan koefisien regresi positif sebesar 24.662 dengan tingkat signifikansi (p) sebesar 0,998 lebih besar dari $\alpha=5 \%$. Dengan tingkat signifikansi yang lebih besar dari $\alpha=5 \%$ maka Ha2 ditolak dan Ho2 diterima .

\section{Pengaruh Reputasi KAP (X3) terhadap Audit Delay}

Dalam penelitian ini menunjukan Variabel Reputasi KAP menghasilkan koefisien regresi positif sebesar 1.978 dengan tingkat signifikansi (p) sebesar 0,349 lebih besar dari $\alpha=5 \%$. Dengan tingkat signifikansi yang lebih besar dari $\alpha=5 \%$ maka Ha3 ditolak dan $\mathrm{Ho} 3$ diterima.

\section{Pengaruh Ukuran Perusahaan (X1), Kompleksitas Operasi Perusahaan(X2) dan Reputasi KAP(X3) terhadap Audit Delay(Y).}

Berdasarkan hasil dari Chi Square sebesar 30,111 dengan df sebesar 3 dan signifikansi sebesar 0,000 yang nilainya lebih kecil dari 0,05. Hal ini menunjukkan bahwa Ha4 diterima, sehingga dapat disimpulkan bahwa Ukuran Perusahaan, 
Kompleksitas Operasi Perusahaan dan Reputasi KAP berpengaruh secara simultan terhadap Audit Delay.

\section{KESIMPULAN DAN SARAN}

\section{Kesimpulan}

Dari pembahasan diatas, maka akan dapat ditarik kesimpulan sebagai berikut :

Berdasarkan hasil uji regresi logistik (logistic regression) menunjukkan bahwa ukuran perusahaan secara statistik berpengaruh signifikan terhadap audit delay. Hal ini dibuktikan dengan tingkat signifikansi (p) sebesar 0,017 lebih kecil dari $\alpha$ sebesar 5\% $(0,017<0,05)$ dari nilai Wald sebesar 5,744, Kompleksitas Operasi Perusahaan secara statistik tidak berpengaruh signifikan terhadap audit delay. Hal ini dibuktikan dengan tingkat signifikansi (p) sebesar 0,998 lebih besar dari $\alpha$ sebesar 5\% $(0.998>0,05)$ dari nilai Wald sebesar 0.000 , Reputasi KAP secara statistik tidak berpengaruh signifikan terhadap audit delay. Hal ini dibuktikan dengan tingkat signifikansi (p) sebesar 0,349, lebih besar dari $\alpha$ sebesar 5\% ( 0,349 > 0,05) dari Wald sebesar 0,878, Ukuran perusahaan, Kompleksitas Operasi Perusahan, Reputasi KAP secara simultan berpengaruh signifikan terhadap audit delay. Hal ini dibuktikan dengan hasil dari Chi Square sebesar 30,111 dengan df sebesar 3 dan signifikansi sebesar 0,000 yang nilainya lebih kecil dari $0,05(0,000<0,005)$.

\section{Saran}

Berdasarkan hasil kesimpulan diatas, maka saran yang diberikan bagi penelitian yang akan datang adalah sebagai berikut :

1. Sebaiknya menambahkan variabel - varibel independen lainnya yang dapat mempengaruhi audit delay.

2. Penelitian selanjutnya di harapkan dapat menambahkan periode waktu penelitian. 


\section{DAFTAR PUSTAKA}

Agoes Sukrisno. 2012 .Auditing Petunjuk Praktis Pemeriksaan Akuntan oleh Akuntan Publik,Edisi ke Empat, Buku satu, Penerbit Salemba Empat, Jakarta.

Andi Kartika. 2011. Faktor-Faktor Yang Mempengaruhi Audit Delay Pada Perusahaan Manufaktur Yang Terdaftar Di Bei. Universitas Stikubank.

Angruningrum, S dan Made G.W.2013.Pengaruh Profitabilitas, Leverage, Kompleksitas Operasi, Reputasi Kap dan Komite Audit pada Audit Delay, Ejurnal Akuntansi Universitas Udayana 5.2 hal 255, 265.

Arum Ardiningsih. 2018. Audit Laporan Keuangan,Buku satu,Cetakan pertama Jakarta bumi aksara.

Chotimah Chusnul,2018. Pengaruh Kompleksitas Operasi perusahaan,ukuran perusahaan dan ukuran kantor akuntan publik (KAP) terhadap Audit delay pada perusahaan pertambangan di BEI tahun 2014-2016. Skripsi Akuntansi Institut agama islam Surakarta.

Ghozali, Imam. 2016. Aplikasi Analisis Multivariete Dengan Program IBM SPSS 23 Edisi delapan. Cetakan ke VIII. Semarang, Badan Penerbit Universitas Diponegoro.

Heri. SE, M.si.2017 Auditing Dan Asurans (Integrated and Comprehensive edition) Pemeriksaan Akuntansi berbasis Standar Audit Internasional . Grasindo, jakarta

Husein Umar, 2005. Metode Penelitian. Jakarta : Salemba Empat

Inayati dan Susilowati, 2015.Pengaruh Karakteristik perusahaan dan Auditor terhadap Audit Delay studi kasus pada perusahaan Hotel, Restoran dan Pariwisata di Bursa Efek Indonesia, Jurnal Akuntansi, volume XIX No.03.

Ikatan Akuntansi Indonesia. 2011. Standar Profesional Akuntan Publik (SPAP). Jakarta : Salemba Empat.

Ikatan Akuntansi Indonesia. 2012. Standar Akuntansi Keuangan. Jakarta : Salemba Empat.

Kartika, Andi. 2011. Faktor-Faktor Yang Mempengaruhi Audit Delay Pada Perusahaan Manufaktur Yang Terdaftar Di BEI. Dinamika Keuangan dan Perbankan Vol. 3 No. 2. Program Studi Akuntansi Universitas Stikubank, Semarang.

Mulyadi, 2002, Auditing, Edisi keenam, Cetakan pertama, Jakarta: Salemba Empat Mulyadi. 2017. Auditing, Salemba Empat, edisi 6, cetakan ketiga belas, Buku dua, Penerbit Salemba emapt, Jakarta. 
Ningsih, Catur Wulan. 2014. Faktor-Faktor Yang Mempengaruhi Audit Delay Studi Empiris Pada Perusahaan Consumer Goods Yang Terdaftar di Bursa Efek Indonesia (BEI) Periode 2009-2012. Skripsi. Universitas Maritime Raja Ali Haji.

Pratama, Baradha dan Agustinus Santosa Adiwibowo. 2014. Analisis Faktor faktor yang Mempengaruhi Audit Delay dan Timeliness pada Perusahaan Publik di Indonesia (Studi Empiris pada Perusahaan yang Terdaftar secara Konsisten di LQ45 pada Bursa Efek Indonesia). Diponegoro Journal of Accounting Volume 3 Nomor 2, Tahun 2014.

Rachmawati, Sistya. 2008. Pengaruh Faktor Internal dan Eksternal Perusahaan Terhadap Audit Delay dan Timeliness. Jurnal Akuntansi dan Keuangan, Vol. 10, No.1, 1-10.

Saputri, Oviek Dewi. 2012. Analisis Faktor-Faktor Yang Mempengaruhi Audit Delay. Skripsi. Universitas Diponegoro. Semarang.

Sari, Indah Permata., R.Andri Setiawan, dan Elfi Ilham. Pengaruh Ukuran Perusahaan, Solvabilitas, dan Reputasi KAP Terhadap Audit Delay pada Perusahaan Property \& Real Estate di Bursa Efek Indonesia Periode 2009-2012. Pekanbaru : Faculty of Economics Riau University. JOM FEKON Vol. 1, No.2, Oktober 2014.

Setiawan, Heru. 2013. Pengaruh Ukuran Perusahaan, Reputasi Auditor, Opini Audit, Profitabilitas, Solvabilitas Terhadap Audit Delay pada Perusahaan Keuangan yang Terdaftar di Bursa Efek Indonesia. Skripsi. Jakarta. Fakultas Ekonomi dan Bisnis Universitas Islam Negeri Syarif Hidayatullah.

Sugiyono. 2016. Metode penelitian kuantitatif kualitatif dan kombinasi(Mixed Methods) Bandung, Alfabeta.

Sunaningsih, S. N. (2014). Faktor-faktor yang Berpengaruh terhadap Audit Delay (Studi Empris pada Perusahaan Sektor Jasa yang Terdaftar di Bursa Efek Indonesia Periode Tahun 2011 dan 2012). Skripsi, Universitas Diponegoro Semarang.

Wardhana, Prama Handitya. 2014. "Faktor-faktor internal yang berpengaruh terhadap audit report lag”. Skripsi Tahun 2014.

Widiyastuti, Made Tika. 2016. Pengaruh Ukuran Perusahaan, Kompleksitas Operasi Perusahaan Dan Jenis Industri Terhadap Audit Delay Pada Perusahaan Yang Terdafatar Di Bursa Efek Indonesia Tahun 2011-2014. Jurnal Akuntansi Universitas Udayana. 6(2), h:485-498.

Widyasari, Ester, (2011) “Analisis Faktor-Faktor Yang Mempengaruhi Audit Delay Pada Perusahaan Perbankan Yang Terdaftar Di BEI Tahun 2007-2009”, Skripsi Universitas Pembangunan Nasional Veteran Jatim, hal 3. 
Widosari, Shinta, 2012.Analisis Faktor-Faktor Yang Berpengaruh Terhadap Audit delay Pada Perusahaan Manufaktur Di Bursa Efek Indonesia Tahun 20082010. Skripsi Universitas Diponegoro, hal 24-27.

Yulianti, Ani. 2011. Faktor- Faktor Yang Berpengaruh Terhadap Audit Delay (Studi Empiris Pada Perusahaan Manufaktur Yang Terdaftar Di Bursa Efek Indonesia PadaTahun 2007-2008. Skripsi. Program Studi Akuntansi Jurusan Pendidikan Akuntansi.

Laporan Keuangan 2015, http://www.idx.co.id/id/beranda/perusahaan tercatat/laporan-keuangan-dan-tahunan.aspx, diakses tanggal 20 Maret 2019, $12: 45$.

www.idx.com 